\title{
O nepotismo e a impessoalidade sob a ótica do pós-positivismo jurídico
}

\section{NEPOTISM AND IMPERSONALITY UNDER THE PERSPECTIVE OF POST-POSITIVISM LEGAL}

\author{
Kassio Cardoso Souza * \\ Luciana Gaspar Melquíades Duarte **
}

Resumo: O presente artigo tem por finalidade analisar os motivos que ensejaram a proibição do nepotismo constante na súmula vinculante $\mathrm{n}^{\circ} 13$, bem como as consequências de tal vedação. $\mathrm{O}$ trabalho se propõe a analisar os fundamentos que levaram à vedação do nepotismo e contrastá-los à nova hermenêutica constitucional, com o reconhecimento da força normativa dos princípios. $\mathrm{O}$ estudo faz uma crítica às vedações absolutas, pautadas no radicalismo, que desconsideram a faticidade, e propõe alternativas constitucionalmente aceitas para se evitar a prática do nepotismo enquanto favorecimento pessoal. Propõe, portanto, uma nova leitura do enunciado sumulado com vistas a se preservar a impessoalidade e o real interesse público nas nomeações para os cargos comissionados e funções de confiança.

Palavras-chave: Nepotismo. Pós-positivismo. Impessoalidade. Igualdade. Democracia.

Abstract: The present article has as it's goal analyze the reasons that gave rise to the prohibition of nepotism fixed on the binding precedent $n^{\circ} 13$, as well to analyze the consequences of this

* Kassio Cardoso Souza. Graduando em Direito pela Universidade Federal de Juiz de Fora. Pós-graduando em Direito Público Contemporâneo pela Universidade Federal de Juiz de Fora. E-mail: kassio.cardoso @ufjf.edu.br

** Luciana Gaspar Melquíades Duarte. Professora Adjunta de Direito Administrativo e Constitucional da UFJF. Professora do Programa de Pós-Graduação Stricto Sensu Direito e Inovações. Especialista pela FGV. Mestre e Doutora em Direito Público pela UFMG. E-mail: lg.melquiades@uol.com.br forbiddance. This work has the purpose of analyzing the elements that resulted on the prohibition of nepotism and contrast them with the new constitutional interpretation, with the recognition of the normative force of principles. The study makes a critic over the absolute forbiddances, guided on radicalism, that disregard the facticity, and proposes alternatives constitutionally acceptable to avoid the practice of nepotism as personal fostering. Therefore, it proposes a new reading to the binding precedent $n^{\circ} 13$, trying to preserve impersonality and the real public interest on the designations to commissioned roles and trusted functions.

Keywords: Nepotism. Post-positivism. Impersonality.Iguality. Democracy. 


\section{INTRODUÇÃO}

A Constituição (BRASIL, 1988) estabelece, em seu art. 37, caput, princípios norteadores da função administrativa. Do rol previsto no dispositivo constitucional, encontra-se o princípio da moralidade, ali insculpido com o fito de trazer preceitos de transparência, boa-fé e probidade no trato com a res publica, exigindo, portanto, que o agente público aja com impessoalidade, na medida em que o obriga a adotar uma postura isenta de privilégios e perseguições.

Ocorre que favorecimentos pessoais ocorreram, e ainda ocorrem, nas nomeações para os cargos públicos, em que os administradores aproveitam da função que exercem e acabam por privilegiar parentes e amigos na distribuição dos cargos a serem ocupados. Tais atitudes representam flagrante antijuridicidade, haja vista ferir diversos princípios basilares da ordem jurídica pátria, como a impessoalidade, a isonomia e, em especial, a moralidade, estando afastadas do ethos que permeia a atual Constituição.

Nesse contexto foi editada a Súmula Vinculante número 13 (BRASIL, 2008). A súmula veda o nepotismo, isto é, a contratação de parentes para atuar na Administração Pública. Isto implica a proibição da contratação de irmãos, tios, sobrinhos, pais, avós, entre outros, haja vista que a redação do dispositivo alcança os parentes até o terceiro grau. Veda também o chamado "nepotismo cruzado", qual seja, o ajuste mediante designações recíprocas.

O entendimento do Supremo Tribunal Federal é que tal tipo de contratação implica um favorecimento pessoal que é incompatível com a atuação do gestor público, de modo que viola a Constituição (BRASIL, 1988). Sua observância é obrigatória em todas as esferas da Administração Pública, seja ela direta ou indireta, e em qualquer dos poderes.

Não se duvida que, não raras vezes, a nomeação de parentes fere, $a b$ initio, o princípio da impessoalidade, da eficiência e, por conseguinte, o princípio da moralidade. Sendo assim, há que se combater tais desvios de finalidade, como procurou estabelecer a súmula vinculante aludida.

Contudo, à luz do princípio da moralidade, identificada a aparente ocorrência do nepotismo, as causas da nomeação deveriam ser aferidas, contrastando as aptidões do nomeado com o cargo por ele pretenso, a razoabilidade da remuneração recebida e a persecução do interesse público, com vistas a identificar (ou não) inadequação da nomeação. Somente a partir da aferição desses elementos seria possível identificar algum desvio de finalidade e a consequente violação dos princípios da moralidade e da impessoalidade. 
A leitura da súmula em comento tem que ser oxigenada pela visão póspositivista do Direito. Há que se reconhecer a normatividade dos princípios, isto é, vê-los não apenas como diretrizes ou programas, mas como normas que efetivamente obrigam e geram consequências jurídicas.

Reconhecendo-se a força jurídica dos princípios constitucionais, toda a ordem jurídica deve se conformar aos seus ditames, de forma que terão o condão de determinar a inconstitucionalidade das normas inferiores, além de condicionar todo o ordenamento jurídico e exigir que se elaborem normas infraconstitucionais à sua concretização, como se propõe no Pós-positivismo jurídico, referencial teórico do presente trabalho.

Os princípios constitucionais são normas que baseiam e sustentam toda a lógica do sistema jurídico-constitucional, representando valores supremos e fundamentais do ordenamento jurídico de uma dada comunidade. Sendo assim, não podem ser vistos como meras linhas sugestivas ou meros programas de atuação administrativa, e sim como verdadeiros nortes que acabam por vincular e direcionar a ação do Poder Público e da iniciativa privada, em razão de sua eficácia jurídica vinculante.

O estudo das formas que solucionam os conflitos entre princípios ganha fundamental relevância, em especial se considerar-se a força normativa dos princípios constitucionais. Sendo assim, ao se analisar tal empreitada a partir de uma moderna teoria da argumentação jurídica, estar-se-á diante de uma rediscussão e redefinição da hermenêutica constitucional clássica, que se vale da lógica formal-positivista. Há que adentrar-se num terreno novo, pautado, agora, por uma moderna hermenêutica constitucional, que vai ser vivificada pela aplicação dos princípios da proporcionalidade e razoabilidade.

É assim que se pretende uma (re)leitura da Súmula Vinculante $n^{\circ} 13$ (BRASIL, 2008). Enquanto a limitação antinepotismo visa garantir que o interesse público, e não o privado, seja atendido, coibindo possíveis fraudes, sua generalidade e abstração pode inviabilizar a consecução dos objetivos públicos, além de afetar direitos dos indivíduos de se candidatarem a nomeações por simplesmente terem relações de parentesco com a autoridade nomeante.

Nada mais razoável que conformar a interpretação do enunciado sumulado à luz da visão pós-positivista. Em que pese a existência de (inúmeras!) vozes na doutrina no sentido de proibir práticas como o nepotismo, por representar indícios de favorecimento pessoal e desvio de finalidade da nomeação, haverá casos, em especial em Municípios com baixa densidade populacional, em que pessoas competentes para o cargo, emprego ou função pública, talvez as únicas 
de confiança política do administrador, estarão impedidas de fazê-lo em função de uma vedação por demasiado genérica. Neste caso, atingir-se-ão direitos subjetivos do indivíduo (que fica prejudicado na possibilidade de exercer uma função de confiança ou um cargo comissionado), bem como poderá haver um contrassenso entre a vedação e o interesse público que deve nortear a Administração Pública.

Destarte, nesse trabalho, pretende-se discutir a razoabilidade do verbete vinculante $\mathrm{n}^{\circ} 13$ (BRASIL, 2008) à luz do princípio da igualdade. Vale ressaltar que não se defende uma postura arbitrária do administrador público. O que se quer é que se permita a contratação de parentes em situações em que ela for oportuna e conveniente ao interesse público, respeitando-se o direito de todos ao acesso aos cargos públicos. Como se pode notar, fala-se, aqui, em discricionariedade e não em arbitrariedade.

O objetivo é, portanto, analisar a possibilidade da nomeação de parentes em função das peculiaridades que envolvem os infinitos casos concretos, tendose em vista a dinamicidade da vida frente à abstração e generalidade da vedação do nepotismo constante no enunciado da Súmula Vinculante ${ }^{\circ}$. 13 (BRASIL, 2008), discutindo a possibilidade de contorno da vedação imposta, estabelecendo critérios para a nomeação e reconhecendo uma discricionariedade necessária na condução da res publica. Para tanto, intenta-se reconhecer a normatividade dos princípios e a superação da mera exegese legal na aplicação do entendimento sumulado, com vistas a se implementar, de acordo com a realidade fática, o real interesse público.

\section{A NORMATIVIDADE CONSTITUCIONAL NO PÓS- POSITIVISMO JURÍDICO}

O ordenamento jurídico, segundo a visão pós-positivista, é um conjunto de normas divididas em duas categorias: regras e princípios. $\mathrm{Na}$ visão de Alexy (2008), os princípios seriam mandamentos de otimização, já que ordenam a realização de seus preceitos na maior medida possível, considerando-se as circunstâncias fáticas e jurídicas existentes. As regras, por sua vez, seriam determinações, devendo ser satisfeitas ou não satisfeitas. Isso quer dizer que se uma norma vale, ela tem que ser aplicada.

Duas regras não podem conviver em caso de conflito. Nessa hipótese, há apenas duas alternativas: ou existe uma cláusula de exceção que elimina o conflito, ou pelo menos uma das regras há que ser declarada inválida. 
Isso se dá porque o conceito de validade jurídica não é gradual. Ou ela é válida, ou não é. Por tal razão, Dworkin (2010) afirma que as regras são aplicáveis à maneira do "tudo-ou-nada". Isto quer dizer que, ocorrendo os fatos que uma regra estipula, então ela será válida, desencadeando efeitos jurídicos, ou não será válida, hipótese em que nada contribuirá para a decisão. A questão central, portanto, quando se tratar do conflito de normas é que a decisão há que se pautar num critério de validade.

Os princípios, ao revés, não estabelecem condições que tornem sua aplicação necessária. Eles enunciam uma diretriz, necessitando de uma decisão particular para sua implementação. Nem por isso deixam de ter força jurídica. É que eles traduzem o ideal do Direito, e, portanto, devem ser aplicados na maior medida possível, em especial porque possuem ampla abrangência, facilitando o choque com outros princípios.

Quando do conflito entre dois ou mais princípios, os interesses terão que ser sopesados, haja vista que, abstratamente, eles têm o mesmo peso. Isso porque um princípio restringe as possibilidades jurídicas do outro. A solução, portanto, há que se pautar nas circunstâncias concretas delineadas, o que nos leva a falar em relação de precedência condicionada. Em outras palavras, fixadas certas condições, um princípio terá prevalência; sob outras circunstâncias, é possível que a colisão seja resolvida de forma diversa.

Os princípios desempenham, na visão pós-positivista, um papel fundamental nos argumentos que sustentam as decisões a respeito de direitos e obrigações jurídicas particulares. São, porém, comandos prima facie, conforme ressalta Alexy (2008). Não há, pelo menos aprioristicamente, precedências absolutas ou abstratas, isto é, nenhum interesse apresenta, em si mesmo, precedência sobre o outro. Há apenas a possibilidade de relação condicionada, isto é, precedência concreta. É assim difundida a metáfora do peso. A colisão principiológica é resolvida pelo sopesamento, considerando o que Dworkin (2010) chama de força relativa de cada interesse em jogo.

A Constituição está repleta de normas, que podem ser regras ou princípios. Não há que se duvidar da força normativa dos princípios no atual estágio de desenvolvimento da ciência jurídica. As normas nela insculpidas gozam da possibilidade de gerar consequências jurídicas, ainda que sejam comandos prima facie. A nova hermenêutica constitucional vem pregar que as normas constitucionais não são meros parâmetros ou diretrizes. Não existem, na 
Constituição, normas meramente programáticas. Elas obrigam e geram consequências jurídicas e não podem, por isso, ser ignoradas pelos operadores do Direito.

Assim é a impessoalidade, norma de extrema importância numa sociedade democrática e plural. Ela traz em seu bojo o princípio da igualdade, grande postulado da democracia, haja vista todos serem iguais perante a le $i^{I}$. Sendo assim, não há que se aceitar, sob pena de se ferir a impessoalidade e, consequentemente, a isonomia, qualquer atuação discriminatória ou mesmo privilegiadora, por parte da Administração Pública, sem que se tenha no próprio texto constitucional respaldo para tal tratamento diferenciado.

A sociedade é plural, e deve ser justa e igualitária. Sendo assim, exigese da Administração Pública atuação desprovida de interesses particulares, sob pena de se incorrer em desvio de finalidade. O objetivo do ato administrativo deve ser a persecução do interesse público, de modo que ficam vedadas perseguições motivadas por interesses privados, bem como favorecimentos pessoais. Atuar assim é um dever mais que moral, é jurídico.

A norma contida no texto do art. 37 em comento traz a obrigatoriedade de respeito aos padrões de legalidade, impessoalidade, moralidade, publicidade e eficiência, exigindo seu cumprimento tanto pela Administração direta quanto indireta, obrigando igualmente os três poderes. Sendo assim, Executivo, Legislativo e Judiciário devem pautar sua conduta respeitando o que o constituinte denominou de princípio da impessoalidade.

A impessoalidade em relação ao agente público traz o dever de agir despido de interesses privados. Deve ele buscar a concretização dos fins públicos, atuando em prol de toda coletividade. Nesse sentido, a impessoalidade se confunde com o princípio da finalidade. Por outro giro, exige a impessoalidade que a Administração atue sem discriminações e privilégios, tratando os destinatários com igualdade, de modo que se confunde com o princípio da isonomia. Ambos os princípios supranarrados também gozam de força constitucional.

Cabe, aqui, indagar: se a impessoalidade é um princípio, poderia ela ser afastada numa situação de precedência condicionada? Isto é, poderia o operador do Direito atuar com parcialidade, pautado em interesse privado, em dada situação?

${ }^{1}$ BRASIL (1988) Art. $5^{\circ}$ Todos são iguais perante a lei, sem distinção de qualquer natureza, garantindo-se aos brasileiros e aos estrangeiros residentes no País a inviolabilidade do direito à vida, à liberdade, à igualdade, à segurança e à propriedade, nos termos seguintes: [...]. 
Parece que a resposta a essa questão é não. À Administração Pública não é permitido atuar fora dos padrões de impessoalidade, sob pena de se ferir ou o interesse público que deve ser perseguido ou a isonomia. Em qualquer hipótese, restaria violada a ordem constitucional vigente. Ademais, permitir que o agente público faça tal juízo quando da sua atuação, seria o mesmo que lhe conferir uma discricionariedade demasiada, sem fundamento legal, ferindo também o princípio da legalidade que, no caso da Administração Pública, permite apenas sua atuação pautada na lei.

Sendo assim, não parece vislumbrar-se na impessoalidade a característica de princípio. Ela não traz apenas um norte, um comando prima facie. Pelo contrário, traz um comando definitivo, na medida em que exige sempre uma postura impessoal da Administração Pública.

Haverá casos, é certo, em que o tratamento desigual será necessário, para implementação de uma igualdade material. Nesses casos, entretanto, haveria que se estabelecer critérios para aferição da constitucionalidade do descrímen, de maneira que restasse configurada uma exceção à regra, e não o afastamento de um princípio pelo sopesamento.

O que se pretende aqui afirmar é que, caso se trate a impessoalidade como princípio, ela poderia ceder frente a outros princípios, ou sucumbir diante da realidade fática, haja vista que a implementação dos princípios é guiada pelas possibilidades jurídicas e fáticas existentes no momento de sua aplicação. Tal, entretanto, não representa uma alternativa viável se se tomar como base a ordem constitucional vigente, que exige segurança jurídica nas relações sociais, inclusive com a Administração Pública.

Tratar a impessoalidade como regra, por sua vez, seria dar a ela o condão de definitividade: ocorrendo certa situação, ela tem que ser aplicada na lógica do "tudo-ou-nada", porque é válida. Somente não será aplicada nas hipóteses em que haja uma exceção prevista, isto é, quando se tiver um descrímen constitucionalmente averiguado, de forma a se implementar a faceta substancial da isonomia.

\section{EVOLUÇÃO JURISPRUDENCIAL DAS DECISÕES ACERCA DO NEPOTISMO}

É certo que a edição da Súmula Vinculante n. 13 (BRASIL, 1988) foi o ápice de todo o processo evolutivo da doutrina e da jurisprudência a fim de dar efetividade à impessoalidade e à moralidade, nortes da Administração Pública, 
visando coibir práticas seculares reprováveis daqueles que estiveram à frente do Poder Público, qual seja, a busca por favorecimentos pessoais, incompatíveis com a noção de isonomia e de Estado Democrático de Direito. A evolução do entendimento do Supremo Tribunal Federal (STF) acerca do controle do nepotismo acentuou-se com a Ação Declaratória de Constitucionalidade (ADC) $n^{0}$ 12, pleiteada pela Associação dos Magistrados do Brasil (BARROSO, 2006).

A ADC em comento tinha por escopo tornar imperativa a Resolução $n^{\circ}$ 07/05 (BRASIL, 2005), do Conselho Nacional de Justiça (CNJ), que dispunha sobre os impedimentos acerca da nomeação de parentes de serventuários e magistrados em cargos de livre nomeação no Poder Judiciário.

Decidiu-se, conforme o entendimento da época, que as práticas nepotistas representam flagrante violação à moralidade e à impessoalidade, contrariando o que determina a própria Constituição (BRASIL, 1988). Sendo assim, pela força normativa que os princípios ganham na visão pós-positivista do Direito, obrigando a conformação de toda a ordem jurídica aos seus comandos, não podem sobreviver atos administrativos que representem violação à tábua axiológica máxima do ordenamento jurídico.

Neste sentido, podemos citar excerto da petição inicial da Ação Declaratória de Constitucionalidade $\mathrm{n}^{\mathrm{0}} 12$ :

Do núcleo dos princípios da moralidade e da impessoalidade extraem-se determinadas regras de forma imediata, sendo que uma delas é, sem dúvida, a que veda o favorecimento pessoal no acesso a cargos públicos e na celebração de contratos, isto é: as práticas de nepotismo. A rigor, esse comando é instrumentalizado pelas técnicas do concurso público e da licitação. Note-se que o fato de a Constituição haver considerado a técnica do concurso inconveniente na hipótese dos cargos em comissão não afasta a incidência da regra que veda o favorecimento pessoal ou familiar nesse contexto. (BARROSO, 2006).

Em tal processo, cujo relator foi o ilustre Ministro Carlos Ayres Brito, o Supremo Tribunal Federal buscava dar efetividade ao art. 37 da Constituição (BRASIL, 1988), em especial no que tange à carga impositiva dos princípios insculpidos em seu caput, que exigem atuação da Administração Pública pautada nos padrões de legalidade, impessoalidade, moralidade, publicidade e eficiência em relação à res publica.

A Resolução $n^{\circ} 07$ do CNJ (BRASIL, 2005), conforme a visão do relator, não discriminava o Poder Judiciário frente aos outros Poderes da República, 
objetivando, apenas, explicitar os lindes para as nomeações livres no Judiciário. O fez, portanto, nos limites de sua competência. Isso não quer dizer que os Poderes Legislativo e Executivo estariam completamente livres para as nomeações dos cargos em comissão e funções de confiança, haja vista que o ordenamento jurídico brasileiro, conforme entendimento da Corte Suprema, não permite atos administrativos que afrontem aos ditames da impessoalidade, moralidade, ou eficiência.

Outros instrumentos normativos, anteriores à edição do verbete vinculante número 13, também tratavam do tema, tais como as resoluções do Conselho Nacional do Ministério Público, regimentos internos de Tribunais e estatutos de servidores públicos de entes federativos. Todos eles, entretanto, têm aplicação tópica, não se aplicando de forma genérica, mas apenas pontual, para destinatários específicos.

$\mathrm{O}$ argumento da defesa de moralidade administrativa impera. Tal proibição não poderia dar-se apenas no âmbito do Poder Judiciário. Neste sentido, o Ministro do Supremo Tribunal Federal, Ricardo Lewandowisk, no julgamento do Recurso Extraordinário (RE) $n^{\circ} 579951$, em que atua como relator, assim dispõe em sede de doutrina:

Sabemos que o Estado, no exercício das atividades administrativas que lhe são inerentes, não pode ignorar os princípios essenciais, que, derivando da constelação axiológica que confere substrato ético às ações do poder público, proclamam que as funções governamentais, não importa se no âmbito do Poder Executivo, no âmbito do Poder Legislativo ou no domínio do Poder Judiciário, hão de ser exercidas com estrita observância dos postulados da igualdade, da impessoalidade e da moralidade administrativa.

Esses princípios, erigidos à condição de valores fundamentais pela Carta Política, representam pauta de observância necessária por parte dos órgão estatais. Mais do que isso, Senhor Presidente, tais postulados qualificam-se como diretrizes essenciais que dão substância e significado à repulsa que busca fazer prevalecer, no âmbito do aparelho do Estado, o sentido real da ideia republicana, que não tolera práticas e costumes administrativos tendentes a confundir o espaço público com a dimensão pessoal do governante, em claro desvio de caráter ético-jurídico. (BRASIL, 2008a).

Há explicitado, no excerto acima transcrito, o reconhecimento da normatividade dos princípios constitucionais. A visão pós-positivista, no sentido de dar efetividade aos comandos da Constituição (BRASIL, 1988), independente de se traduzirem em regras ou princípios, permeia todo o desenrolar da decisão. 
Fato é que, em 29 de agosto de 2008, representando verdadeiro ápice normativo sobre o tema, fora publicada no Diário Oficial da União (DOU) a Súmula Vinculante $n^{\circ} 13$, do Supremo Tribunal Federal, com o fito de combater o nepotismo em todo o âmbito do serviço público, seja ele federal, estadual, municipal ou do Distrito Federal. Eis o verbete vinculante ${ }^{\circ} 13$, in verbis:

A nomeação de cônjuge, companheiro ou parente em linha reta, colateral ou por afinidade, até o terceiro grau, inclusive, da autoridade nomeante ou de servidor da mesma pessoa jurídica investido em cargo de direção, chefia ou assessoramento, para o exercício de cargo em comissão ou de confiança ou, ainda, de função gratificada na administração pública direta e indireta em qualquer dos Poderes da União, dos Estados, do Distrito Federal e dos Municípios, compreendido o ajuste mediante designações recíprocas, viola a Constituição Federal. (BRASIL, 2008b).

Destarte, a partir desta data, a Súmula Vinculante $\mathrm{n}^{\circ} 13$ do STF tem eficácia, permitindo a operacionalização dos seus efeitos, submetendo os órgãos não apenas do Poder Judiciário, mas também dos Poderes Executivo e Legislativo às suas determinações.

A vedação constante do enunciado sumulado é bem específica, dirigindose aos parentes, consanguíneos ou afins, que forem nomeados para exercer cargos em comissão, de confiança ou função gratificada. Sendo assim, caso se trate de nomeação de cargos de provimento efetivo, ou mesmo contratação temporária de pessoal, tal será ato administrativo hígido, mesmo que o indicado seja cônjuge, companheiro ou parente até o terceiro grau, inclusive, da autoridade nomeante ou de servidor público investido em cargo de direção, chefia ou assessoramento da mesma pessoa jurídica. Isto se dá porque estas últimas espécies de cargos não estão mencionadas no entendimento sumular, de maneira que não incide a proibição.

Por óbvio, a vedação se destina somente aos cargos cujo provimento independe de qualquer processo seletivo público, sendo livre a escolha dos titulares pela autoridade nomeante. Havendo procedimento seletivo público, seja ele simplificado ou concurso, como ocorre, respectivamente, com a contratação temporária de pessoal e a nomeação para exercício de cargo efetivo, não há que se falar em qualquer favorecimento pessoal, nem violação dos ditames da impessoalidade, moralidade ou eficiência. Em tais cargos, observa-se o princípio da isonomia entre os postulantes ao preenchimento das vagas oferecidas. 
Por outro lado, para o provimento dos cargos públicos comissionados de direção, chefia ou assessoramento, ou para funções de confiança, outros parâmetros também devem ser observados. Isso porque os servidores investidos em tais cargos desempenham atribuições de coordenação dos demais serviços prestados pela Administração Pública, além de serem incumbidos do próprio funcionamento da máquina administrativa.

Estes servidores públicos sujeitam-se diretamente ao administrador público, e são hierarquicamente superiores a tantos outros servidores. Por tal razão, exige-se que sejam pessoas da confiança da autoridade nomeante, comungando de sua ideologia e buscando auxiliá-lo no trato com a res publica. Há que haver afinidade política, de maneira que não é viável processo seletivo para a nomeação desse tipo de pessoal.

Não se está aqui falando que a escolha deve ser pautada em afinidade pessoal. Muito pelo contrário: é bem possível que o gestor público tenha afinidades pessoais com certos indivíduos, mas que politicamente haja um abismo ideológico entre ambos. Sendo assim, a escolha daquele que exercerá a função de livre nomeação há que ter um caráter político. É o que a própria Constituição (BRASIL, 1988) tentou estabelecer quando permitiu a livre nomeação e exoneração em tais cargos.

O Estado de Direito encontra na democracia um dos seus principais alicerces. O pluralismo político, representando as diversas ideologias, bem como a soberania popular exercida, em grande parte dos casos, pelos partidos políticos, atuam como instrumento de efetivação da vontade popular. Neste sentido, Ernest Böckenförd (2000), ao estudar o tema, acaba por alçar a soberania popular como norte da própria democracia, como diretriz que orienta o princípio democrático. E mais, afirma que o exercício do poder somente será legitimado quando derivar do povo, de maneira concreta. Somente se assim for, poder-seá dizer que se está num Estado de Direito em sentido substancial.

Os partidos políticos e as coligações representam, então, pelo menos em tese, certa ideologia. Considerando que todo poder emana do $\mathrm{povo}^{2}$, o partido ou coligação referendado nas urnas ganha legitimidade para atuar em nome de toda a coletividade. O Chefe do Executivo eleito carrega consigo a bandeira de uma ideologia que foi a escolhida pelo povo no momento do sufrágio. Sendo

\footnotetext{
${ }^{2}$ BRASIL (1988). Art. $1^{\circ}$. A República Federativa do Brasil, formada pela união indissolúvel dos Estados e Municípios e do Distrito Federal, constitui-se em Estado Democrático de Direito e tem como fundamentos: [...] Parágrafo único. Todo o poder emana do povo, que o exerce por meio de representantes eleitos ou diretamente, nos termos desta Constituição.
}

REVISTA DO DIREITO PÚBLICO, Londrina, v.8, n.3, p.9-32, set./dez.2013 
assim, cabe a ele oxigenar toda a máquina administrativa com a legitimidade recebida, e o faz ao indicar os cargos de livre nomeação e exoneração. Estabelece, assim, verdadeira cadeia de legitimidade, fazendo com que toda a estrutura administrativa do Estado seja condicionada à vontade referendada no pleito eleitoral.

Por todas as razões demonstradas supra, a própria Constituição (BRASIL, 1988) confere ampla liberdade de nomeação e exoneração no que tange ao provimento desses cargos. ${ }^{3}$

São, portanto, sobre os cargos de livre nomeação e exoneração que a vedação constante da Súmula Vinculante $n^{\circ} 13$ (BRASIL, 1988) incide. Além disso, não se pode olvidar do princípio da universalidade do acesso aos cargos públicos, previsto em nosso texto constitucional vigente, constituindo verdadeiro direito do cidadão de buscar o ingresso no serviço público como forma de trabalho, independente do vínculo de parentesco que mantenha com agentes públicos.

É importante salientar que o conteúdo do verbete vinculante $\mathrm{n}^{\circ} 13$ também não alcança os cargos de natureza eminentemente política. Tal foi o conteúdo extraído do julgamento do Recurso Extraordinário nº 579951, publicado em 24 de outubro de 2008.

O entendimento vem mitigar a súmula, no sentido de que a proibição não alcança os chamados agentes políticos, haja vista que tais cargos não têm meramente natureza administrativa. É o que se pode concluir do voto do Ministro Ayres Britto, no julgamento do referido Recurso Extraordinário:

Então, quando o art. 37 refere-se a cargo em comissão e função de confiança, está tratando de cargos e funções singelamente administrativos, não de cargos políticos. Portanto, os cargos políticos estariam fora do alcance da decisão que tomamos na $\mathrm{ADC} \mathrm{n}^{\circ} 12$, porque o próprio capítulo VII é $\mathrm{Da}$ Administração Pública enquanto segmento do Poder Executivo. E sabemos que os cargos políticos, como por exemplo, o de secretário municipal, são agentes de poder, fazem parte do Poder Executivo. O cargo não é em comissão,

\footnotetext{
${ }^{3}$ BRASIL (1988) Art. 37. A administração pública direta e indireta de qualquer dos Poderes da União, dos Estados, do Distrito Federal e dos Municípios obedecerá aos princípios de legalidade, impessoalidade, moralidade, publicidade e eficiência e, também, ao seguinte: (Redação dada pela Emenda Constitucional $\mathrm{n}^{\circ} 19$, de 1998)[...] II - a investidura em cargo ou emprego público depende de aprovação prévia em concurso público de provas ou de provas e títulos, de acordo com a natureza e a complexidade do cargo ou emprego, na forma prevista em lei, ressalvadas as nomeações para cargo em comissão declarado em lei de livre nomeação e exoneração; (Redação dada pela Emenda Constitucional n ${ }^{\circ} 19$, de 1998).
} 
no sentido do artigo 37. Somente os cargos e funções singelamente administrativos - é como penso - são alcançados pela imperiosidade do artigo 37, com seus lapidares princípios. Então, essa distinção me parece importante para, no caso, excluir do âmbito da nossa decisão anterior os secretários municipais, que correspondem a secretários de Estado, no âmbito dos Estados, e ministros de Estado, no âmbito federal. (BRASIL, 2008a).

Os agentes políticos, na visão do ilustre administrativista Carvalho Filho (2009), são caracterizados pela função de direção e orientação que possuem, e por ser transitório o exercícios de tais funções. Sua investidura se dá, via de regra, por meio de eleições, conferindo-lhe um mandato que, pela natureza da própria República e democracia, tem caráter transitório. Não se sujeitam ao mesmo regime dos demais agentes públicos, tendo suas prerrogativas e responsabilidades designadas na própria Constituição. Pode-se dizer que são agentes de poder.

Constituem a cúpula diretiva do Estado, tomando as decisões eminentemente políticas. Tal espécie de agentes públicos englobaria, de acordo com a doutrina moderna, somente aqueles que exercem função realmente política, atuando em nome e em prol de toda a coletividade, sendo responsáveis pelo implemento das diretrizes políticas e planos governamentais. É o caso do Presidente da República, dos Governadores e Prefeitos, dos Senadores, Deputados e Vereadores.

Por terem o âmbito de atuação delineado pela própria Constituição, a categoria de agentes políticos gera dissenso conceitual na doutrina. Meirelles (2005) doutrina no sentido de que tal espécie de agentes públicos alberga todos aqueles que recebem atribuições previstas no próprio texto constitucional. Partindo dessa lógica, estariam enquadrados na categoria de agentes políticos os magistrados, o membros do Ministério Público e dos Tribunais de Contas, entre tantos outros. O ilustre doutrinador acrescenta que, após a Emenda Constitucional $\mathrm{n}^{\mathrm{o}} 19$, os agentes políticos podem ser identificados como aqueles que recebem seus salários por meio de subsídio. Percebe-se, portanto, que o tema não se encontra sedimentado em sede doutrinária.

Com a devida venia, o posicionamento do Professor Meirelles (2005) não parece de todo correto. Ora, é certo que é a Carta Política do Estado a responsável por delinear direitos, deveres, responsabilidades, garantias e prerrogativas funcionais dos agentes políticos, mas o simples fato de serem mencionados no texto constitucional não é condição suficiente para serem considerados agentes de poder. São agentes políticos aqueles que exercem 
efetivamente função política e não apenas de modo eventual, assumindo função de administração, governo, de comando. Em suma, são os responsáveis por traçar o destino estratégico do Estado. Resta excluído de tal grupo, portanto, os membros do Poder Judiciário, do Ministério Público e dos Tribunais de Contas, entre outros.

Os agentes de poder realizam atos de soberania estatal, atuando com ampla liberdade decisória, haja vista que possuem o condão de avaliar a conveniência, oportunidade, adequação e eficiência na prática de certos atos, traduzindo a vontade do Estado. São, assim, agentes vocacionados à persecução do interesse público, e legitimados pelo povo para cumprir tal mister.

O Supremo Tribunal Federal, ao editar o verbete ${ }^{0} 13$, fê-lo da forma mais radical possível. Entretanto, o próprio STF - como se pode extrair do inteiro teor do acórdão proferido no Recurso Extraordinário mencionado supra - limitou-se a delimitar o âmbito de incidência do entendimento sumulado, excluindo a aplicação do verbete às nomeações de agentes políticos, atuando num entendimento que acabaria por justificar a edição da Súmula Vinculante $\mathrm{n}^{\mathrm{o}} 13$.

O distinguishing operado pelo STF, quanto à incidência da Súmula antinepotismo, pauta-se na diferenciação entre função de governo e função administrativa, diferenciando-se, por conseguinte, o regime jurídicoconstitucional dos agentes políticos e agentes administrativos. Sendo assim, a vedação, em certos casos, e a permissão, em outros, acabaria por não violar os princípios constitucionais, e sim, respeitar o desenho institucional realizado pelo Constituinte Originário, permitindo a persecução do interesse público primário. Tal foi o argumento utilizado.

Considerou o Supremo Tribunal Federal que os cargos de primeiro escalão, verbi gratia, os Ministros de Estado e Secretários Estaduais e Municipais, estariam englobados na categoria de agentes políticos, não estando sujeito às proibições contidas na súmula antinepotismo.

Entretanto, não aprofundou a motivação. O Egrégio Tribunal não analisou os pormenores que justificam a submissão, ou não, dos agentes políticos às mesmas regras aplicáveis aos agentes administrativos, faltando uma fundamentação. Trata-se de uma alternativa que encontrou a Suprema Corte para contornar um enunciado por demasiado genérico e restritivo.

A conclusão acima mostra que as vedações absolutas não devem ser regra nos ordenamentos democráticos e na atual conjuntura e desenvolvimento da consciência jurídica, haja vista que a dinamicidade da 
realidade fática não pode ser subsumida ao mero encaixe legal, sob pena de se cometer injustiças das mais variadas espécies. É o que se percebe quando se abandona a lógica positivista e se entra no campo da normatividade constitucional.

Portanto, a síntese a que se chega é que o entendimento consolidado da jurisprudência dos Tribunais Superiores há que ser revisto, à luz dos princípios que com ele possam colidir, de maneira que se afigura válida e digna de reflexão e ponderação tais indagações e questionamentos acerca da (in)aplicabilidade da Súmula Vinculante $n^{\circ} 13$ (BRASIL, 2008) em função dos delineamentos do caso concreto.

\section{PROPOSIÇÕES À APLICAÇÃO DA SÚMULA VINCULANTE $N^{0} 13$}

Até agora, se procurou criticar a generalidade da súmula antinepotismo, em especial diante da dinamicidade da realidade fática. Haverá casos, como se tentou demonstrar, em que a vedação contida no enunciado sumulado irá de encontro ao real interesse público, muito embora a pretexto de protegêlo, além de revelar ofensa à igualdade. Não é possível, aprioristicamente, taxar como imoral toda e qualquer contratação de parentes para o exercício de função de confiança ou cargo em comissão.

Sendo assim, alternativa possível seria permitir a contratação de parentes da autoridade nomeante, desde que tal escolha obedeça a certos parâmetros, a fim de se averiguar a finalidade da contratação, e o respeito aos princípios da moralidade, eficiência e impessoalidade.

O que se propõe é uma releitura do enunciado sumular sob a ótica do Pós-Positivismo jurídico, com vistas a se efetivar conjuntamente, na maior medida do possível, todos os princípios constitucionais que regem a Administração Pública.

Limitar toda e qualquer contratação de parentes, tal qual fez o Supremo Tribunal Federal ao editar a Súmula Vinculante $n^{\circ} 13$, pode representar uma afronta aos fins públicos. A escolha do ocupante da função de confiança ou cargo em comissão deve ser feita entre o maior número de postulantes possível, facilitando a seleção do gestor público. A nomeação há que ser, entretanto, pautada em critérios político-ideológicos, e não em afinidades pessoais, como já se afirmou acima. 
O leque de possibilidades há que ser extenso, haja vista que a escolha errada de um funcionário de alto escalão pode gerar consequências das mais desastrosas para os administrados. Está-se falando de agentes responsáveis pela elaboração e implementação de políticas públicas, que aludem a necessidades reais da população, de maneira que um erro na nomeação pode prejudicar o desempenho do papel social de um órgão público, além de sacrificar a capacidade do país de alcançar resultados estratégicos.

O controle da moralidade e da eficiência deve ser feito, portanto, por uma fiscalização rigorosa sobre os critérios e processos de recrutamento, e não pela proibição genérica. Há que se estabelecer um critério de meritocracia. O indivíduo nomeado tem que demonstrar aptidão para desempenhar as funções inerentes ao cargo comissionado ou função de confiança. Um secretário de Estado, verbi gratia, sem experiência no campo em que pretende atuar, ou sem uma equipe qualificada para desempenhar os fins públicos, pode prejudicar, ou mesmo retardar, a prestação de serviços públicos, muitos deles essenciais.

Habermas (2009) traz a noção de uma ação racional teleológica, instrumental, traduzindo-se no domínio dos processos que constituem a evolução da sociedade, através do controle comportamental dos indivíduos segundo os modelos de competência estabelecidos pelo atual sistema de produção, com suas regras e estratégias. Defende, então, que a questão do conhecimento, o domínio da razão técnica, é uma questão política. Prossegue, afirmando que:

[...] o método científico, que levava sempre a uma dominação cada vez mais eficaz da natureza, proporcionou depois também os conceitos puros e os instrumentos para uma dominação cada vez mais eficiente do homem sobre os homens, através da dominação da natureza. (HABERMAS, 2009, p. 49).

E não para por aí. Habermas (2009) defende que, segundo Marcuse, a dominação prolifera não apenas "mediante a tecnologia", mas "como tecnologia". Daí se pode concluir que a tecnologia acaba por dar legitimação ao poder político, controlador de todas as esferas da sociedade.

Entretanto, acaba por concluir que técnica e a ciência são enquadramentos institucionais funcionalmente necessários nas sociedades atuais, já que contribuem para o domínio da natureza pelo homem, assegurando um conhecimento maior sobre os fenômenos naturais, além de 
propiciar à sociedade mais conforto, através da evolução da produção técnica. A visão do teórico da ação comunicativa não é no sentido de se questionar o fundamento da ciência e tecnologia, mas suas aplicações concretas e historicamente situadas. As ações humanas são dirigidas a fins, através de uma interação comunicativa.

Há que se concluir que a capacidade técnica é, portanto, apenas um meio, não um fim em si mesmo, para auxiliar a persecução do interesse público. Não se quer defender, neste trabalho, uma tecnocracia, criticada por Habermas (2009). De maneira alguma um governo de técnicos, excluindo a participação do povo, seria uma alternativa viável. O povo é o destinatário das políticas públicas e, portanto, é elemento essencial para determinar as demandas e necessidades públicas, que serão objeto de atuação dos governantes.

Todavia, o nomeado há que ser uma pessoa com um mínimo de capacitação ou formação profissional na sua área de atuação, de maneira que, conjuntamente com a população, possa traduzir os anseios sociais em ações efetivas. A sociedade precisa de garantias de que o nomeado seja o mais apto a desenvolver a função a ele designada, conhece a área e já passou por situações semelhantes às que terá que enfrentar no desempenho do múnus público. Deve ele ter um conhecimento mínimo necessário para formular as políticas públicas daquele segmento de serviço público, coordenar as atividades a serem executadas, bem como dialogar com os diversos setores da sociedade, a fim de atingir o interesse público.

O que se propõe, neste estudo, é a exigência de alguma qualificação profissional compatível com as tarefas a serem desenvolvidas na função de confiança ou cargo em comissão. $O$ ato de nomeação deverá ser acompanhado de alguma certificação que demonstre aptidão profissional para o exercício da função pública. Seja, a título exemplificativo, um diploma de nível superior ou técnico, contendo pertinência temática com o âmbito de atuação do pretenso agente público. Com tal requisito, já se estaria evitando nomeações ao arrepio da capacidade laboral do pretenso agente.

A eficiência estará respeitada, pelo menos em tese, se o nomeado for capacitado para o exercício das funções que lhe forem atribuídas. Neste diapasão, doutrina Antonio (2009, p. 15):

É que o nepotismo gera duas situações. Uma é totalmente moral, adequada ao Ordenamento Jurídico e não pode ser abarcada pela vedação sumular. 
Trata-se das nomeações de pessoas hábeis, eficientes, vocacionadas, que trabalham duro e desempenham bem suas funções na Administração Pública, e mais, são parentes da autoridade nomeante, gozando, por isso, de relação de confiança com ela. Estes servidores são perfeitos para exercerem cargos em comissão ou funções de confiança, nos termos previstos pela Constituição da República. De forma alguma se pode dizer que suas nomeações atentam contra o interesse público e o princípio da eficiência.

Sendo determinado indivíduo capacitado para a função e detentor da confiança do administrador, não há no ato má-fé, desonestidade ou desvirtuação da finalidade pública. Ao contrário, a finalidade pública pode ser amplamente atendida no caso de o servidor comissionado, em que pese ter relação de parentesco com quem o nomeou, cumprir satisfatoriamente suas funções, em estrita observância ao princípio da eficiência.

Diferentemente, o nepotismo pode promover a realização de interesses particulares, em detrimento do interesse público, empregando pessoas no serviço público que não detêm as qualidades necessárias. Essa situação caracteriza indisfarçável imoralidade e justificou a edição da Súmula.

Com tal entendimento busca-se salvaguardar a moralidade e a eficiência na Administração Pública, adotando uma postura impessoal, fazendo uma interpretação teleológica do verbete antinepotismo. A finalidade da decisão do Supremo Tribunal Federal é evitar que detentores de cargos com elevado prestígio junto à Administração Pública venham a beneficiar parentes, sem qualquer critério de controle.

O requisito da formação técnica afim ao cargo busca evitar a contratação por apadrinhamento político, e, por outro ângulo, pretende favorecer a eficiência no desempenho das funções estatais. Note que se estará coibindo favorecimentos pessoais não apenas de parentes da autoridade nomeante ou agentes comissionados, mas também de amigos íntimos, que, não raras vezes, ingressam na Administração Pública sem qualquer tipo de preparo.

Não basta, entretanto, o controle apenas no ato de nomeação. Deve ele ser estendido ao efetivo exercício das funções atinentes ao cargo que ocupa, perfazendo todo o trajeto que o indivíduo percorrerá na função pública que exerce. Sendo assim, há que se aferir se o nomeado está exercendo regularmente suas funções, bem como analisar os resultados obtidos nas avaliações de desempenho a que deve ser submetido. 
Não deve ser, porém, o nomeado submetido às avaliações de desempenho tradicionais, voltadas para os servidores ocupantes de cargos efetivos. Há que se estabelecer um controle sobre a efetividade das funções desempenhadas, através de análises estatísticas, consultas públicas, entre outros, para garantir o respeito aos ditames constitucionais, em especial no que tange à eficiência. Neste contexto, a participação popular seria de grande valia, haja vista que é um bom indicador da legitimidade dos programas e ações desenvolvidos. Observando tal critério, não há que se falar em nomeação imoral, pessoal ou ineficiente.

Também deve haver motivação da nomeação. A autoridade nomeante há que explicitar os fundamentos de fato e de direito que levaram àquela escolha, sob pena de se tornar a nomeação nula. Assim, permitir-se-á uma maior transparência e honestidade na contratação, ao possibilitar que a coletividade possa analisar os motivos ensejadores da nomeação. A razoabilidade da nomeação há que ser aferida em cada caso, respeitando-se as nuances infinitas que a realidade fática pode assumir. Em outros termos, é no caso concreto que se procederá à verificação da aceitabilidade da nomeação.

Para tal mister, condicionar a nomeação ao crivo do Tribunal de Contas do respectivo ente da federação poderia ser medida útil ao combate de eventuais desvios de finalidade. $\mathrm{O}$ ato administrativo ficará condicionado à ratificação ou refutação pelo Tribunal de Contas, órgão responsável pela análise da legalidade - em sentido amplo - da medida.

Observando os critérios supramencionados restará protegido o interesse público, ao possibilitar a análise da moralidade da nomeação. Será permitida a nomeação de parentes, desde que fundamentada, com análise de sua capacidade $^{4}$, da razoabilidade da nomeação e do contraste entre a remuneração recebida e as funções efetivamente desempenhadas. É uma alternativa mais racional, e constitucionalmente aceita, haja vista que se estará respeitando a impessoalidade, a eficiência e o livre acesso aos cargos públicos.

\footnotetext{
${ }^{4}$ Tal exigência deve ser relativizada em certos casos. Na hipótese de não se ter nenhum postulante à nomeação com alguma titulação para o exercício do cargo, a flexibilização do requisito é fundamental. E tal situação é possível de ocorrer na realidade fática. Pode-se aqui citar, a título exemplificativo, o Estado de Minas Gerais, que tem centenas de Municípios, grande parte deles albergando uma população reduzida. Está-se falando aqui de verdadeiras "minicidades", isto é, Municípios constituídos por poucas famílias, como é o caso de Pedra Dourada - MG, ou de Vieiras - MG, contando, respectivamente, com 2.191 e 3.731 habitantes, conforme o censo de 2010 do Instituto Brasileiro de Geografia e Estatísticas (IBGE). Em tais situações excepcionais, poder-se-ia exigir que o nomeado apresentasse aptidões mínimas ao exercício das atividades pretensas, bem como exigir que frequentasse algum curso de capacitação afim à sua área de atuação, dispensando a apresentação de certificado de curso superior ou técnico. Em todo caso, a eficiência deve ser preservada.
} 
Com efeito, qualquer outra medida pautada pelo radicalismo, eivada de paixão, como foi a edição do verbete vinculante $n^{\circ} 13$, tende a ser exagerada, e pode ferir outros princípios, indo de encontro à lógica do sistema constitucional vigente.

\section{CONSIDERAÇÕES FINAIS}

Pela leitura do texto constitucional vigente, em especial do capítulo que trata da Administração Pública e dos seus princípios norteadores, percebe-se que já existe a proibição do nepotismo. Ora, se o gestor público tem o dever de atuar com impessoalidade, e pautar sua conduta pelos padrões de moralidade e eficiência, é certo que a nomeação de parentes com o fito de favorecimento pessoal viola a Constituição (BRASIL, 1988).

Como se procurou demonstrar, os princípios insertos na Constituição Federal de 1988 - em especial a moralidade, impessoalidade e eficiência, bem como a razoabilidade - atuam como mandamentos nucleares do sistema administrativo brasileiro, impondo aos agentes públicos o dever de atuação pautada na ética e na probidade, tendo sempre em vista a persecução do interesse público, de maneira que a administração não pode atuar para beneficiar ou prejudicar pessoas determinadas.

Sendo assim, cabe ao aplicador do Direito, à luz dos princípios constitucionais, verificar se a nomeação para os cargos públicos respeita o ordenamento jurídico pátrio. Para tal mister, deve-se proceder à análise sistemática de toda a ordem jurídica, e buscar a efetivação dos princípios basilares e dos mandamentos que destes defluem, sem desconsiderar, é claro, as peculiaridades da situação concreta.

Dessa feita, estar-se-á coibida a prática reiterada, imoral, e até mesmo ilegal, da nomeação indiscriminada de dezenas de amigos e parentes, em especial quando objetivamente se mostram desqualificados e inexperientes, para o exercício de cargos públicos. Tais nomeações são atos ilícitos, censuráveis pela lógica constitucional, na medida em que representam um descompasso com os princípios que regem a atuação administrativa.

$\mathrm{Na}$ defesa da moralidade administrativa foi então editada a Súmula Vinculante $n^{\circ} 13$. A aplicação do verbete em toda e qualquer hipótese, como se tem frisado ao longo de todo este trabalho, acaba por trazer sérias violações à Constituição (BRASIL, 1988), apesar do pretenso argumento de defendê-la. 
Isso se dá em função de não se poder generalizar questão tão subjetiva, em especial no que tange a cargos que exigem uma relação de fidúcia quando do seu preenchimento. A relação de confiança entre a autoridade nomeante e o nomeado situa-se na essência dos cargos a serem ocupados. Isso porque a autoridade faz a sua escolha pela afinidade politica que tem, de maneira que os parentes podem ser a única opção em que ela confie para o exercício daquela função, para a plena consecução das atribuições a ela inerentes.

É, portanto, indevida a presunção de que qualquer parente de agente público que exerça cargos em comissão ou funções de confiança o faz em virtude apenas de seu vínculo familiar, sem preencher qualquer outra condição para o exercício do serviço público. É uma análise desprovida de qualquer verificação da pertinência do agente com o cargo exercido, de maneira que se revela verdadeiro preconceito, haja vista taxá-los, de plano, de corruptos. Exonerar servidores públicos e vetar a nomeação de pessoal em razão da relação de parentesco com aqueles que ocupam cargos públicos, configura inegável discriminação, consubstanciando em violação a diversos princípios como a isonomia, bem como violação ao princípio da universalidade de acesso dos brasileiros aos cargos e funções públicas, ou mesmo da indisponibilidade do interesse público. Considerando-se, abstrata e genericamente, qualquer nomeação de parentes de agentes públicos como inconstitucional, constituir-se-á uma sociedade em que ter algum parente que seja autoridade pública será mácula impeditiva ao acesso à Administração Pública, mesmo nas hipóteses em que a lei permitir.

Assim, caso se leve às últimas consequências a proibição do nepotismo por si só, acabariam por se extinguir, na estrutura funcional do Estado, os cargos em comissão e as funções de confiança, que, como já demonstrado, acabam por oxigenar toda a máquina administrativa através de uma cadeia de legitimidade.

A causa da imoralidade administrativa, no enfoque ora estudada, não reside apenas na prerrogativa de livre nomeação e exoneração de servidores, mas, também, no caráter das pessoas investidas de Poder Público. Por isso, imprescindível a análise de cada caso concreto. Apenas dessa forma terse-ia um controle mais eficaz da moralidade na Administração Pública. Notese que não se trata de controle apriorístico, feito pela edição de normas e súmulas gerais e abstratas, aplicáveis a todas as hipóteses indefinidamente, mas sim de análise minuciosa de cada situação concreta. 
Sendo assim, a moralidade das nomeações de servidores para cargos em comissão ou funções de confiança pode ser aferida pela sua razoabilidade. Na análise de cada caso, deve-se indagar se é, ou não, razoável a nomeação. Em outras palavras, no caso concreto, se é aceitável, ou não, a nomeação de um parente da autoridade nomeante ou de servidor investido em cargo de direção, chefia ou assessoramento para exercer cargo comissionado ou função de confiança.

Haverá, não eventualmente, casos em que a violação aos preceitos de probidade, decoro e boa-fé revelarão uma imoralidade patente, seja pela exacerbada quantidade de parentes que ocupam cargos públicos em determinado ente federativo, seja pelo despreparo e inabilidade gritante do servidor para o exercício das atribuições do seu cargo ou por outros motivos que revelem a inadequação e irrazoabilidade da nomeação. São estas as hipóteses a serem evitadas e não aquelas em que o nomeado demonstre aptidão para a concretização das finalidades públicas.

Por tal razão é que se defendeu a releitura do verbete vinculante $n^{\circ}$ 13, com vistas a uma aplicação teleológica do enunciado sumulado, bem como uma interpretação lógico-sistemática de todo o ordenamento, dando verdadeira efetividade aos princípios norteadores da função administrativa. É o que determina a vertente do pós-positivismo jurídico.

Em suma, não é o nepotismo em si a causa do descontentamento, mas os abusos e os desvios de finalidade cometidos, não raras vezes, por aqueles que se encontram à frente da máquina pública.

Portanto, criando-se os mecanismos de controle, defendidos neste trabalho, restará preservada a legalidade e higidez da nomeação. Em qualquer hipótese, caberá, ainda, a fiscalização por parte da população e dos órgãos de controle, como, exempli gratia, o Ministério Público, podendo, na defesa da moralidade administrativa, recorrer à tutela encabeçada pelo Poder Judiciário, que deverá proceder à análise caso a caso.

\section{REFERÊNCIAS}

ALEXY, Robert. Teoria dos direitos fundamentais. 2. ed. São Paulo: Malheiros, 2008.

ANTONIO, Alice Barroso de. O nepotismo sob a ótica da Súmula Vinculante $n^{0} 13$ do STF: críticas e proposições. Revista Brasileira de Direito Municipal - RBDM, Belo Horizonte, ano 10, n. 31, jan./mar. 2009. 
BARROSO, Luís Roberto. Ação Declaratória de Constitucionalidade. 2006. Disponivel em:<http://www.abdconst.com.br/

publicacoes_artigos_mostra.php?id=4>. Acesso em: 23 ago. 2013.

BATISTA, Patrícia. Transformações do direito administrativo. Rio de Janeiro: Renovar, 2003.

BÖCKENFÖRD, Ernest Wolfgang. Estudios sobre el Estado de Derecho y la democracia. Madrid: Trotta, 2000. p. 17-55.

BRASIL. Constituição (1988). Constituição da República Federativa do Brasil. Brasília, 1988.

BRASIL. Conselho Nacional de Justiça. Resolução $\mathbf{n}^{\mathbf{0}}$ 7, de 18 de outubro de 2005. http://www.cnj.jus.br/atos-administrativos/atos-da-presidencia/323resolucoes/12121-resolu-no-7-de-18-de-outubro-de-2005-> . Acesso em: 12 abr. 2013.

BRASIL. Supremo Tribunal Federal. Recurso Extraordinário 579.951/ RN. 2008a. p. 5. Disponível em: $<$ http://redir.stf.jus.br/paginadorpub/ paginador.jsp?docTP=AC\& docID=557587>. Acesso em: 10 fev. 2013.

BRASIL. Supremo Tribunal Federal. Súmula Vinculante $\mathbf{n}^{\mathbf{0}}$ 13. 2008 b. Disponível em: <http:/www.dji.com.br/normas_inferiores/ regimento_interno_e_sumula_stf/0013vinculante.htm $>$.Acesso em: 1 jul. 2013.

CARVAlHO FILHO, José dos Santos. Manual de Direito Administrativo. Rio de Janeiro: Lumen Juris, 2009.

DWORKIN, Ronald. Levando os Direitos a sério. 3. ed. São Paulo: Martins Fontes, 2010.

HABERMAS, Jurgen. Técnica e Ciência como "Ideologia". Lisboa: Ed. 70, 2009.

MEIRELLES, Hely Lopes. Direito administrativo brasileiro. 30. ed. São Paulo: Revista dos Tribunais, 2005. 
MELLO, Celso Antônio Bandeira de. Curso de direito administrativo. 18. ed. São Paulo: Malheiros, 2005.

Artigo recebido em: 29/10/2013 Aprovado para a publicação em: 03/12/2013

Como citar: SOUZA, Kassio Cardoso. DUARTE, Luciana Gaspar Melquíades. O nepotismo e a impessoalidade sob a ótica do pós-positivismo jurídico. Revista do Direito Público. Londrina, v.8, n.3, p.9-32, set/dez 2013. DOI: 10.5433/ 1980-511X.2013v8n3p9. 